\title{
ANALYSIS OF FACTORS AFFECTING INCOME OF EMPING MELINJO BUSINESS OF HOUSEHOLD SCALE
}

\section{ANALISIS FAKTOR-FAKTOR YANG MEMPENGARUHI PENDAPATAN USAHA EMPING MELINJO SKALA RUMAH TANGGA}

\author{
Nursamsi, Sasmita Siregar, Nurul Iqbal \\ Program Studi Agribsnis Fakultas Pertanian UMSU-Medan \\ email : nursamsi@umsu.ac.id
}

\begin{abstract}
This research was purposed to find out the income, influence of production factors such as venture capital, materials, and workers with income of emping melinjo's household scale, to know appropriateness level of emping melinjo's household scale business. The result showed that average income of emping melinjo business was Rp.613.968,75 / month. The statistical test of R-square value of $0.98 \%$ simultaneously, there was a close relationship between venture capital, materials and workers with income of emping melinjo's household scale $98 \%$ the rest was influenced by other factors that were not studied, it was supported by the value of f-count 304,285> f-table 2.95 at $95 \%$ confidence level. The calculation of R / C Ratio obtained value of 1.97 , this value meant that the business emping malinjo household scale was feasible to cultivate
\end{abstract}

Keywords: Income, Household Scale, Emping Melinjo

\section{ABSTRACT}

Penelitian ini bertujuan adalah untuk mengetahui seberapa besar pendapatan, pengaruh faktorfaktor produksi seperti modal usaha, bahan baku, dan tenaga kerja terhadap pendapatan usaha emping melinjo skala rumah tangga, mengetahui tingkat kelayakan usaha emping melinjo skala rumah tangga. Hasil penelitian yang dilakukan menunjukkan rata-rata pendapatan usaha emping melinjo sebesar Rp.613.968,75/bulan. Hasil pengujian statistik nilai R-square sebesar 0,98 \% mengartikan bahwa secara simultan (serempak) ada hubungan yang erat antara modal, bahan baku, dan tenaga kerja terhadap pendapatan usaha emping melinjo skala rumah tangga sebesar $98 \%$ selebihnya dipengaruhi oleh faktor lain yang tidak diteliti, hal ini didukung oleh nilai f-hitung 304,285 > f-tabel 2,95 pada taraf kepercayaan $95 \%$. Dari hasil perhitungan R/C Ratio diperoleh nilai 1,97 degan nilai ini berarti bahwa usaha emping malinjo skala rumah tangga layak untuk diusahakan.

Kata kunci: Pendapatan, Skala Rumah Tangga, Emping Melinjo

\section{A. PEndahuluan}

Pertanian dalam arti luas terdiri dari lima sektor yaitu tanaman pangan, perkebunan, peternakan, perikanan dan kehutanan. Kelima sektor pertanian tersebut bila ditangani lebih serius sebenarnya akan mampu memberikan sumbangan yang besar bagi perkembangan perekonomian Indonesia mendatang, salah satu penanganannya yaitu dengan perkembangan perekonomian pada bisnis pertanian atau agrobisnis. ${ }^{1}$

Industrialisasi pertanian dikenal dengan nama agroindustri, dimana agroindustri dapat menjadi salah satu pilihan strategis dalam menghadapi masalah dalam upaya peningkatan perekonomian masyarakat di pedesaan serta mampu menciptakan kesempatan kerja bagi masyarakat yang hidup di pedesaan. Sektor industri pertanian merupakan suatu sistem pengelolaan secara terpadu antara sektor pertanian dengan sektor industri guna mendapatkan nilai tambah dari hasil pertanian. Agroindustri merupakan usaha untuk meningkatkan efisiensi sektor pertanian hingga menjadi kegiatan yang sangat produktif melalui proses modernisasi pertanian. Modernisasi di sektor industri dalam skala nasional dapat meningkatkan penerimaan nilai tambah sehingga pendapatan ekspor akan lebih besar. ${ }^{2}$

Agroindustri diharapkan dapat memainkan peranan penting dalam kegiatan pembangunan daerah, baik dalam pemerataan pembangunan, pertumbuhan ekonomi, maupun stabilitas nasional. Keberadaan agroindustri di pedesaan diharapkan dapat meningkatkan permintaan terhadap komoditas pertanian, karena sektor agroindustri sangat berperan dalam mengubah produk pertanian menjadi barang yang lebih bermanfaat. ${ }^{3}$

Terdapat beberapa kriteria jenis industri menurut Badan Pusat Statistik (BPS),yaitu: 1) Industri Besar adalah perusahaan industri yang 
mempunyai tenaga kerja 100orang atau lebih. 2) Industri Sedang adalahperusahaan industri yang mempunyai tenaga kerja antara 20 sampai 99 orang. 3) Industri Kecil adalah perusahaan industri yang mempunyai tenaga kerja antara 5 sampai 19 orang. 4) Industri Mikro adalahperusahaan industri yang mempunyai tenaga kerja antara 1 sampai 4 orang. Industri Kecil dan Mikro (IKM) sebagai bagian dari industri pengolahan merupakan industri yang menciptakan dan menyerap tenaga kerja yang cukup besar. ${ }^{4}$

Industri mikro yang berkembang di Indonesia adalah salah satunya di bidang pangan. Menurut (Taty,2009), keberadaan industri pangan di Indonesia dapat menyerap tenaga kerja dalam jumlah yang cukup banyak serta mampu mendorong berdirinya industri penunjang seperti industri pengolahan makanan dan industri kemasan yaitu suatu industri yang memproduksi kemasan suatu produk seperti kemasan berbahan baku plastik, kertas, kaca, dan lainnya. ${ }^{5}$

Salah satu bentuk industri mikro pengolahan makanan yang mengubah hasil pertanian menjadi suatu produk baru yaitu usaha industri pengolahan melinjo (G. gnemon) menjadi suatu produk olahan baru. ${ }^{6}$

Di Indonesia, melinjo merupakan tanaman yang tumbuh tersebar di mana-mana, serta banyak ditemukan di tanah-tanah pekarangan penduduk desa maupun penduduk perkotaan. Melinjo banyak manfaatnya, dimana hampir seluruh bagian tanaman ini dapat dimanfaatkan. Daun muda yang disebut dengan so, bunga yang disebut dengan kroto, kulit biji tua dapat digunakan sebagai bahan sayuran yang cukup populer di kalangan masyarakat. Bahkan kulit biji yang sudah tua setelah diberi bumbu dan kemudian digoreng akan menjadi makanan ringan yang disebut dengan gangsir yang cukup lezat. Buah yang sudah tua merupakan bahan baku pembuatan emping melinjo yang mempunyai nilai ekonomi yang cukup tinggi. Semua bahan makanan yang berasal dari tanaman melinjo mempunyai kandungan gizi yang cukup tinggi. ${ }^{7}$

Pada umumnya proses pembuatan emping melinjo itu menggunakan cara menggoreng sangan. Dengan dilengkapi pasir, maka biji-biji melinjo yang digoreng sangan akan dapat masak secara merata karena pasir sifatnya cepat menerima panas (dari api tungku atau kompor) dan dengan mencampurkan biji-biji melinjo berbaur dengan pasir yang panas sambil dibolak-balik, maka kemasakan biji melinjo dapat merata. Selain itu, dengan cara menggoreng sangan maka aroma dan zat-zat yang terkandung di dalam biji melinjo itu tidak hilang, sehingga akan diperoleh emping melinjo yang rasanya lezat. Lain halnya bila direbus, aroma dan zat-zat yang tekandung dalam biji melinjo akan larut dalam air rebusan.
Akibatnya, rasa empingnya kurang lezat dan aromanya yang khas itu banyak berkurang. ${ }^{8}$

Melinjo merupakan tumbuhan tahunan berbiji terbuka, berbentuk pohon yang berumah dua (dioecious, ada individu jantan dan betina). Bijinya tidak terbungkus daging tetapi terbungkus kulit luar.Batangnya kokoh dan bisa dimanfaatkan sebagai bahan bangunan.Daunnya tunggal berbentuk oval dengan ujung tumpul. Melinjo tidak menghasilkan bunga dan buah sejati karena bukan termasuk tumbuhan berbunga.Yang dianggap sebagai buah sebenarnya adalah biji yang terbungkus oleh selapis aril yang berdaging. Tanaman melinjo dapat tumbuh mencapai 100 tahun lebih dan setiap panen raya mampu menghasilkan melinjo sebanyak $80-100 \mathrm{Kg}$, Bila tidak dipangkas bisa mencapai ketinggian $25 \mathrm{~m}$ dari permukaan tanah.Tanaman melinjo dapat diperbanyak dengan cara generatif (biji) atau vegetatif (cangkokan, okulasi, penyambungan dan stek). ${ }^{9}$

Di Desa Wonorejo Kecamatan Pematang Bandar Kabupaten Simalungun terdapat berbagai macam jenis usaha makanan olahan dan salah satunya adalah usaha pembuatan emping malinjo. Usaha pembuatan emping melinjo di desa wonorejo sebesar 32 unit yang menduduki posisi pertama, kemudian urutan kedua usaha pembuatan kelanting/alen-alen sebesar 9 unit, usaha pembuatan tempe sebesar 6 unit, usaha pembuatan opak ubi sebesar 3 unit, dan yang terakhir usaha pembuatan ikan lele saleh sebesar 2 unit. Hal ini menunjukkan bahwa usaha pembuatan emping melinjo merupakan salah satu industri yang potensial dan mampu bertahan ditengah persaingan dengan industri makanan lain di Desa Wonorejo Kecamatan Pematang Bandar Kabupaten Simalungun.

Analisis kelayakan merupakan suatu kegiatan yang mempelajari secara mendalam tentang suatu usaha atau bisnis yang dijalankan, dalam rangka menentukan layak atau tidak usaha tersebut dijalankan. Kelayakan artinya pelaksanaan penelitian secara mendalam untuk menentukan apakah usaha yang dijalankan akan memberikan manfaat lebih besar dibandingkan dengan biaya yang dikeluarkan. ${ }^{10}$

Dalam menganalisis kelayakan usaha tersebut salah satunya menggunakan R/C Ratio (Revenue Cost Ratio).R/C rasio (Revenue Cost Ratio) merupakan ukuran rasio untuk mengukur kelayakan suatu usahatani. Komponen yang digunakan untuk analisis ini adalah penerimaan dan total biaya produksi. ${ }^{11}$

Kenyataan inilah yang mendorong peneliti mengadakan suatu penelitian mengenai analisis faktor-faktor yang pempengaruhi pendapatan usaha emping melinjo skala rumah tangga di Desa wonorejo Kecamatan Pematang Bandar Kabupaten Simalungun. 
Adapun yang menjadi tujuan dari pelaksanaan penelitian ini adalah untuk mengetahui pengaruh modal, bahan baku, dan tenaga kerja, terhadap tingkat pendapatan yang diterima oleh para pengusaha emping melinjo skala rumah tangga serta untuk mengetahui kelayakan usaha emping melinjo skala rumah tangga di Desa Wonorejo Kecamatan Pematang Bandar Kabupaten Simalungun.

\section{B. METODE PENELITIAN}

Metode Penentuan Lokasi Penelitian

Dilakukan secara sengaja
(purposive).Penelitian ini dilakukan di Desa Wonorejo, Kecamatan Pematang Bandar, Kabupaten Simalungun, Sumatera Utara.Desa ini sebagian penduduknya memiliki usaha industri emping melinjo skala rumah tangga.

\section{Metode Penelitian}

Metode penelitian ini menggunakan studi kasus (case study). Studi kasus merupakan metode yang menjelaskan jenis penetitian mengenai studi objek tertentu selama kurun waktu tertentu dengan cukup mendalam.

\section{Metode Penarikan Sampel}

Pada penelitian ini, penarikan sampel menggunakan Total Sampling.Sampel dalam penelitian ini adalah rumah tangga yang melakukan usaha pembuatan emping melinjo dalam satu kawasan. Jumlah populasi dalam penelitian ini adalah 32 rumah tangga, dimana apabila subjeknya kurang dari 100 orang, lebih baik diambil semua ${ }^{12}$. Jadi metode pengambilan ini mengambil keseluruhan jumlah populasi untuk dijadikan sampel (sensus) dengan jumlah sebanyak 32 responden

\section{Metode Pengumpulan Data}

Jenis data yang digunakan dalam penelitian ini adalah data primer dan data sekunder.Data primer adalah data yang didapat dari hasil wawancara langsung dengan responden melalui daftar pertanyaan (kuisioner).Sedangkan Data sekunder adalah data yang diperoleh dari instansi yang relevan dengan penelitian seperti BPS.

Metode Analisis Data

untuk menguji rumusan masalah pertama digunakan metode regresi linier berganda dengan rumus :

Dimana :

$$
Y=a+b_{1} x_{1}+b_{2} x_{2}+b_{3} x_{3}+e
$$

$\mathrm{Y}=$ Pendapatan Usaha Emping Melinjo Skala

Rumah Tangga (Rp)

a $\quad=$ Konstanta

$b_{1} b_{2} b_{3}=$ Koefisien Regresi

$x_{1}=$ Penyediaan Bahan Baku $(\mathrm{Rp} / \mathrm{Kg})$

$$
\begin{array}{ll}
x_{2} & =\text { Tenaga Kerja }(\mathrm{Rp} / \mathrm{Hk}) \\
x_{3} & =\text { Produksi }(\mathrm{Rp} / \mathrm{Kg}) \\
e & =\text { Eror } \\
& \text { Untuk menguji pengaruh secara parsial }
\end{array}
$$
digunakan uji t dengan rumus :

$$
t-\text { hitung }=\frac{b i}{\mathrm{~S} b i}
$$

$\mathrm{t}$ hit $>\mathrm{t}$ tabel, Ho ditolak, Hi diterima $\mathrm{t}$ hit $<\mathrm{t}$ tabel, Ho diterima, Hi ditolak.

$$
F-\text { hitung }=\frac{J k \operatorname{Reg} / k}{J k \operatorname{Reg}(n-k-1)}
$$

Dimana :

$\mathrm{Jk}$ Reg $=$ Jumlah kuadrat regresi

Jk Res $=$ Jumlah kuadrat sisa

$\mathrm{k}=$ Jumlah variabel

$\mathrm{n}=$ Jumlah sampel

$1=$ Bilangan

Kaidah tertentu apabila :

F-hit > F-tabel, maka Ho ditolak, Hi diterima F-hit $<$ F-tabel, maka Ho diterima, Hi ditolah

$$
R / C=\frac{\text { Total Penerimaan }}{\text { Total Biaya }}
$$

$\mathrm{R} / \mathrm{C}$ Ratio $\geq 1$, berarti usaha akan memperoleh keuntungan.

$\mathrm{R} / \mathrm{C}$ Ratio $\leq 1$, berarti usaha akan mengalami kerugian dengan demikian lebih baik mencari alternatif usaha lain yang menguntungkan.

\section{Lokasi Penelitian}

Desa Wonorejo terletak di Kecamatan Pematang Bandar, Kabupaten Simalungun, Provinsi Sumatera Utara.Desa ini merupakan desa memiliki potensi alam yang sangat banyak termasuk hasil bumi seperti sayur-sayuran, tanaman perkebunan dan perikanan. Hal ini ditandai dengan tingginya tingkat produktivitas lahan di desa ini dalam menghasilkan komoditaskomoditas pertanian serta dilihat dari mata pencaharian penduduk yang sebagian besar merupakan petani dan perikanan.

Karakteristik Sampel Pengusaha Emping Melinjo Pengusaha industri emping melinjo merupakan pengusaha yang memang berusaha dibidang industri emping melinjo dimana pengusaha ini mendapatkan penambahan pendapatan untuk kehidupannya berasal dari usaha emping melinjo. Prospek usaha ini sangat menguntungkan, bukan hanya ksrena bahan baku yang mudah didapat untuk daerah tersebut, proses pembuatannya pun tidak terlalu rumit dan panjang, hanya proses pemipihan saja yang memerlukan ketrampilan khusus. Pada usaha industri skala rumah tangga ini juga memberikan peluang untuk penyerapan tenaga kerja yang ada didesa, sehingga 


\section{NURSAMSI, SASMITA SIREGAR, NURUL IQBAL}

mengurangi jumlah pengangguran di sekitar daerah penelitian.

Sampel penelitian ini berjumlah 32 responden, mereka rata-rata bermata pencaharian sebagai petani dan untuk mengetahui lebih jelasnya tentang karekteristik pengusaha sampel dapat dilihat pada tabel 1 dibawah ini :

Tabel 1. Karakteristik Pengusaha Sampel Desa Wonorejo Kecamatan Pematang Bandar Kabupaten Simalungun.

\begin{tabular}{cl}
\hline No & Uraian \\
\hline 1 & Umur (Tahun) \\
2 & Pendidikan (Tahun) \\
3 & Jumlah Tanggungan (Jiwa) \\
4 & Pengalaman (Tahun) \\
5 & Modal (Rp)
\end{tabular}

49

2
21

\section{HASIL DAN PEMBAHASAN}

Hasil penelitian dapat diketahui bahwa produksi, biaya produksi, penerimaan, dan pendapatan yang diterima oleh pengusaha emping melinjo berbeda beda, ini disebabkan dengan tingkat kemampuan pengusaha yang juga berbedabeda, ada kemungkinan dipengaruhi oleh variabel yang diteliti (Modal, Bahan Baku, dan Tenaga Kerja).

Untuk melihat rata-rata produksi, biaya produksi, penerimaan, pendapatan pengusaha sampel selama 1 bulan dapat dilihat pada Tabel 2 berikut ini :

8,43 Tabel 2. Rataan Produksi, Biaya Produksi, 2 Penerimaan, Pendapatan Pengusaha Sampel.

$314.312,5 \mathrm{No}$

Sumber : Data Primer Yang Diolah,2017.

Tabel diatas dapat dilihat dari rataan tingkat umur pengusaha emping melinjo adalah 49 tahun artinya bahwa para pengusaha sampel berada pada kelompok umur usia produktif, dengan demikian dapat disimpulkan bahwa pengusaha pengusaha tersebut masih memiliki kemampuan yang potensial dalam melakukan usaha.

Pendidikan sangat berpengaruh terhadap kemajuan usaha emping melinjo karena sangat berhubungan dengan wawasan dan daya serap pengusaha dalam menelaah atau memahami setiap informasi yang berguna bagi kemajuan usahanya. Jenjang pendidikan rata - rata adalah 8,43 tahun, ada pula pengusaha yang tidak bersekolah dan tidak sedikit pengusaha yang memiliki pendidikan hanya sampai SD saja. Hal ini dapat dilihat dari jumlah rataan pada bagian pendidikan.

Jumlah tanggungan perlu untuk dibahas karena sangat berhubungan dengan pengeluaran petani.Semakin banyak jumlah tanggungan maka semakin banyak pula beban atau pengeluaran yang dikeluarkan oleh pengusaha.Dari data yang telah diolah rata - rata jumlah tanggungan pengusaha adalah 2 (Orang).

Rata - rata pengalaman pengusaha sampel dalam usaha emping melinjo adalah 21 tahun, dari keterangan ini dapat disimpulkan bahwa pengusaha yang menjadi sampel di Desa Wonorejo ini telah memiliki pengalaman, pengetahuan, serta keahlian yang cukup dalam kegiatan usaha emping melinjo.

$\begin{array}{lll}1 & \text { Produksi (Kg/Bulan) } & 102,70 \\ 2 & \text { Biaya Produksi (Rp/Bulan) } & 1.952 .750 \\ 3 & \text { Penerimaan (Rp/Bulan) } & 2.566 .718,75 \\ 4 & \text { Pendapatan (Rp/Bulan) } & 613.968,75\end{array}$

Data Primer Diolah, 2017.

Tabel diatas dapat diketahui bahwa hasil produksi rata-rata pengusaha emping melinjo adalah 102,70 Kg/Bulan, harga perkilo emping yang dihargai dengan Rp. 25.000 dengan rata-rata biaya produksi Rp. 1.952.750 untuk satu bulan produksi. Dengan demikian diperoleh rata-rata penerimaan pengusaha emping melinjo berkisar Rp. 2.566.718,75. Angka penerimaan ini bukan sepenuhnya milik petani karena pendapatan pengusaha emping melinjo akan dikurangi dengan total biaya produksi, dan penerimaan dikurangi lagi dengan biaya produksi sehingga diperoleh rata-rata pendapatan pengusaha emping melinjo adalah Rp. 613.968,75/ Bulan.

Analisis Faktor-Faktor Yang Mempengaruhi Pendapatan Usaha Emping Melinjo Skala Rumah Tangga.

Untuk lebih jelasnya melihat pengaruh faktor - faktor yang mempengaruhi pendapatan usaha emping melinjo skala rumah tangga dapat dilihat pada Tabel 3 berikut ini :

Tabel 3. Hasil Analisis Regresi Linier Berganda Antara, Modal, Bahan Baku, Tenaga Kerja Terhadap Pendapatan Usaha Emping Melinjo Skala Rumah Tangga.

\begin{tabular}{lcccc}
\hline \multicolumn{1}{c}{ Variabel } & Koefisien Regresi & Standart Eror & T-Hitung & F-Hitung \\
\hline Modal & -3.453 & 2.817 & -1.226 & 121.146 \\
Bahan Baku & 0.49 & 0.215 & 2.277 & \\
Tenaga Kerja & 1.308 & 0.310 & 4.214 &
\end{tabular}




\begin{tabular}{lc} 
Konstanta & 278552.552 \\
$\mathrm{R}-$ Square & 0.928 \\
Adjusted R - Square & 0.921 \\
Multiple - R & 0.964 \\
$\mathrm{~T}-$ tabel & 1.7011 \\
$\mathrm{~F}-$ tabel & 2.95 \\
\hline Data Primer Diolah, 2017. &
\end{tabular}

Tabel diatas dapat diketahui bahwa analisis regresi linier berganda adalah sebagai berikut :

$$
\mathrm{Y}=278552.552-3.453 X_{1}+0.49 X_{2}+1.308 X_{3}+\mathrm{e}
$$

Hasil dari pengujian data diketahui nilai koefisien determinasi ( $\mathrm{R}$ - Square) dari penelitian ini adalah 0.928 dimana nilai ini mengindikasikan bahwa secara simultan (serempak) pendapatan pengusaha emping melinjo di pengaruhi oleh modal, bahan baku, dan tenaga kerja sebesar 92,8 $\%$ selebihnya dipengaruhi oleh faktor lain diluar variabel sebesar 7,2 \%. Dari hasil pengujian statistik diperoleh nilai multiple $\mathrm{R}$ square sebesar 0.964 mengartikan bahwa secara menyeluruh ada hubungan yang erat antara modal, bahan baku, dan tenaga kerja terhadapan pendapatan pengusaha emping melinjo yaitu sebesar 96,4 \%. Hal ini didukung oleh nilai $\mathrm{f}$ - hitung 121,146 > f - tabel 2.95 pada taraf kepercayaan $95 \%$ (a 0,05$)$, dengan demikian $H_{1}$ diterima dan $H_{0}$ ditolak yang berarti ada pengaruh nyata antara modal, bahan baku, dan tenaga kerja terhadap pendapatan pengusaha emping melinjo dapat dilihat pada uraian berikut ini :

Pengaruh Modal Terhadap Pendapatan Pengusaha Emping Melinjo

Hasil pengujian uji $t$ untuk modal diperoleh nilai $\mathrm{t}-$ hitung $-1,226<\mathrm{t}-$ tabel 1,70 pada tingkat kepercayaan $95 \%$. Dengan demikian $H_{0}$ diterima dan $H_{1}$ ditolak yang berarti modal tidak berpengaruh nyata terhadap penambahan pendapatan pengusaha emping melinjo. Artinya apabila modal ditambah satu satuan maka akan menurunkan pendapatan sebesar $3.453 \%$. Jika dikaitkan dengan keadaan dilapangan hal ini sangat sesuai sekali.Dimana para pengusaha emping melinjo terlalu besar menggunakan modal, sehingga pendapatan yang diharapkan pengusaha emping melinjo tidak terlalu besar.Walaupun pengusaha emping melinjo memperoleh pendapatan yang lumayan besar tetapi tidak sesuai dengan modal yang dicurahkan. Apabila pengusaha tidak hati-hati dalam menggunakan modal, maka akan menyebabkan kerugian tersendiri bagi pengusaha emping melinjo.

Pengaruh Bahan Baku Terhadap Pendapatan Usaha Emping Melinjo

Sebagai salah satu faktor pendapatan disamping modal tentunya ini merupakan hal yang paling esensial dalam peningkatan pendapatan usaha emping melinjo. Dari hasil temuan dilapangan memperlihatkan bahwa jumlah bahan baku yang dipergunakan dalam usaha emping melinjo skala rumah tangga ini adalah dengan ratarata Rp. 883750/bulan.

Dari hasil pengujian dengan uji $t$ diperoleh $\mathrm{t}$ - hitung untuk bahan baku adalah $2.277>\mathrm{t}$ - tabel 1.70 pada tingkat kepercayaan 95 $\%$. Dengan demikian $H_{1}$ diterima dan $H_{0}$ ditolak yang berarti bahan baku berpengaruh nyata terhadap pendapatan pengusaha emping melinjo. Artinya adalah apabila ditambah bahan baku $1 \%$ maka pendapatan akan bertambah $0,49 \%$.

Hal ini sesuai dengan apa yang didapat dari keadaan yang ada dilapangn. Dimana penggunaan bahan baku sangatlah mempengaruhi jumlah produksi sehingga akan menambah pendapatan jika pemanfaat bahan baku dimanfaatkan dengan baik. Saat ini para pengusaha juga berusaha untuk menambah jumlah bahan baku yang mereka pergunakan yang mana nantinya juga akan menambah pendapatan pengusaha emping melinjo skala rumah tangga.

Pengaruh Tenaga Kerja Terhadap Pendapatan Pengusaha Emping Melinjo Skala Rumah Tangga.

Sektor perindustrian kecil maupun industri mikro merupakan salah satu lahan lapangan pekerjaan yang sangat banyak menyita pekerjaan, bukan hanya orang dewasa bahkan anak - anak juga ikut berperan sebagai tenaga kerja , namun dalam hal ini usaha emping melinjo menggunakan tenaga kerja keluarga yang rata rata tenaga kerjanya perempuan. Upah tenaga kerja yang diberikan pada tenaga kerja sebesar Rp. 20.000 / HK. Tenaga yang terpakai dalam usaha ini adalah sebagian besar perempuan atau wanita.

Dari hasil pengujian uji $\mathrm{t}$ untuk tenaga kerja diperoleh nilai $\mathrm{t}$ - hitung 4,214 > t - tabel 1.70 pada taraf kepercayaan $95 \%$ ini berarti $H_{1}$ diterima dan $H_{0}$ ditolak, yang berarti ada pengaruh nyata antara tenaga kerja dengan tingkat pendapatan pengusaha emping melinjo skala rumah tangga. hal ini terjadi karena masih sedikitnya jumlah tenaga kerja yang dicurahkan dalam usaha emping melinjo skala rumah tangga. kondisi objektif daerah penelitian juga memperlihatkan kadaan dimana aktivitas usaha emping melinjo masih sedikit mencurahkan tenaga kerja. Sehingga apabila dilakukan penambahan tenaga kerja akan menambah pendapatan usaha emping melinjo skala rumah tangga. 
Analisis R/C Ratio( Total Penerimaan / Total Biaya ) Usaha Emping Melinjo Skala Rumah Tangga.

Suatu usaha emping melinjo dikatakan layak untuk diusahakan jika petani memperoleh keuntungan yang maksimal dari usaha yang dikelolanya. Manajemen usaha yang baik sangat dibutuhkan dalam pelaksanaan usaha emping melinjo skala rumah tangga, mulai dari pembelian bahan baku, penggunaan peralatan yang mendukung ketekunan dalam mengusahakan sampai dengan sistem pemasaran yang berkelanjutan sangat mendukung terciptanya usaha yang layak untuk diusahakan.

Menurut hasil penelitian yang dilakukan dapat dilihat apakah penerimaan dan pendapatan usaha emping melinjo skala rumah tangga sudah layak ataupun menguntungkan untuk diusahakan oleh masyarakat di Desa Wonorejo Kecamatan Pematang Bandar, Kabupaten Simalungun. Untuk mengetahui tingkat kelayakan usaha emping melinjo skala rumah tangga pada penelitian ini digunakan rumus $\mathrm{R} / \mathrm{C}$ Ratio dengan membandingkan antara penerimaan dengan total biaya produksi yang dikeluarkan dapat dilihat pada Tabel 4 Berikut ini :

Tabel 4. Analisis R/C Ratio ( Total Penerimaan / Total Biaya )

\begin{tabular}{clc}
\hline No & Uraian & Jumlah $(\mathrm{Rp})$ \\
\hline 1 & R (Total Penerimaan) & $2.566 .718,75$ \\
2 & C ( Total Biaya) & 1.952 .750 \\
3 & R/C & 1.314 \\
\hline
\end{tabular}

Data Primer Diolah, 2017.

Melihat tingkat kelayakan usaha emping melinjo skala rumah tangga digunakan analisis $\mathrm{R} / \mathrm{C}$ dengan membagikan penerimaan dengan biaya produksi yang dikeluarkan oleh pengusaha emping melinjo dalam usahanya. Dengan demikian kita akan mengetahui apakah usaha tersebut layak untuk diusahakan (Menguntungkan) atau tidak layak (tidak menguntungkan).

Hasil perhitungan tingkat kelayakan usaha emping melinjo skala rumah tangga yang diperoleh adalah $\mathrm{R} / \mathrm{C}$ sebesar 1,314.Hal ini berarti bahwa usaha emping melinjo sudah dapat memberikan keuntungan kepada pengusaha karena R/C Ratio > 1 ini mengartikan bahwa usaha emping melinjo skala rumah tangga layak untuk diusahakan.

\section{KESIMPULAN}

Dari hasil penelitian yang telah dilakukan terhadap usaha emping melinjo skala rumah tangga dapat diambil beberapa

1. Secara simultan (serempak) ada pengaruh antara modal, bahan baku, dan tenaga kerja terhadap pendapatan usaha emping melinjo skala rumah tangga sebesar 92,8 \% selebihnya dipengaruhi oleh faktor lain yang tidak diteliti, hal ini didukung oleh nilai $\mathrm{F}$ hitung $121,146>\mathrm{F}$ - tabel 2,95 pada taraf kepercayaan $95 \%$.

2. Secara parsial ada pengaruh bahan baku dalam hal ini didukung oleh nilai $\mathrm{t}-2,277>\mathrm{t}$ - tabel 1,70 dan tenaga kerja didukung oleh nilai $\mathrm{t}$ - hitung 4,214> $\mathrm{t}$ - tabel pada taraf kepercayaan $95 \%$. Sedangkan modal tidak berpengaruh nyata terhadap penambahan pendapatan usaha emping melinjo skala rumah tangga. hal ini didukung oleh nilai $\mathrm{t}-$ hitung $-1,226<\mathrm{t}-$ tabel 1,70

3. Tingkat kelayakan usaha emping melinjo skala rumah tangga yang diperoleh adalah $\mathrm{R} / \mathrm{C}$ Ratio sebesar 1,314. Hal ini berarti bahwa usaha emping melinjo skala rumah tangga sudah dapat memberikan keuntungan karena R/C Ratio > 1 ini mengartikan bahwa usaha emping melinjo skala rumah tangga sudah layak.

\section{DAFTARPUSTAKA}

1. Asri.I.W.Y.2010. Analisis Usaha Industri Emping Melinjo Skala Rumah Tangga.Skripsi.Fakultas pertanian.Universitas sebelas maret.Pdf. Diakses pada tanggal 12 oktober 2016.

2. Nugraha,2014.http://e-journal. uajy.ac.id/6454/2/ KOM103709.pdf.Diakses pada tanggal 12 januari 2017.

3. Suriyandi. 1998. Membuat Emping Melinjo. Penerbit Kanisius. Yogyakarta.http:// mobile.fatsecret.co.id/kalori-izi/umum/empingmelinjo.html.

4. Putra.E.P.2013. Karakteristik Tenaga Kerja Terhadap Pendapatan Industri Emping Melinjo. Universitas muhammadiyah Surakarta.pdf.

5. Taty,2009.https://tatyalfiah.files.wordpress.co m/2009/09/klasifikasi-industri1 pdf.).Diakses pada tanggal 12 januari 2017.

6. Ramadhoni. R. 2013 publication. gunadarma.ac.id/ bitstream/123456789/ 8279/1/ slide\%20PI.pdf. diakses pada tanggal 12 Oktober 2016.

7. Ken Suratiyah.2006. Ilmu Usahatani. Penebar Swadaya. Bogor.

8. Sukirno,2005, Peranan Komunikasi Massa Dalam Pembangunan, Gadjah Mada University Yogyakarta.pdf.diakses pada tanggal 12 Oktober 2016. 
9. Suwandi. 1997. Pusat pembinaan usaha kecil dan menengah (PPUKM) LPPM.ikom

10. Syamsuddin.2015. Analisis Perkembangan Emping Melinjo Yang Memperoleh Kredit Dari Koperasi Tani Rejo.Skripsi.Fakultas ekonomi. Universitas diponegoro semarang. Pdf. Diakses pada tanggal 12 oktober 2016.

11. Kasmir dan Jakfar. 2007. Studi Kelayakan Bisnis.pdf.diakses pada tanggal 12 januari 2017.

12. Arikunto.S.2006. Prosedur Penelitian. Rineka Cipta. Jakarta. 